\title{
Fauna diversity, production potential and total economic value of mangrove ecosystems in Mentawir Village, East Kalimantan, Indonesia
}

\author{
ROCHADI KRISTININGRUM ${ }^{1}$, ABUBAKAR M. LAHJIE ${ }^{1, \vartheta}$, MASJAYA $^{2}$, SYAHRIR YUSUF $^{1}$, \\ YOSEP RUSLIM ${ }^{1, \vee v}$, AMIR MA'RUF ${ }^{3}$ \\ ${ }^{1}$ Faculty of Forestry, Universitas Mulawarman. Jl. Penajam, Kampus Gunung Kelua, Samarinda 75123, East Kalimantan, Indonesia.

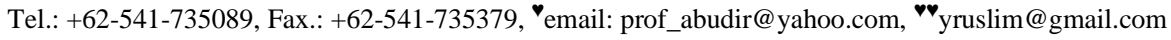 \\ ${ }^{2}$ Faculty of Social and Political Science, Universitas Mulawarman. Jl. Muara Muntai, Kampus Gunung Kelua, Samarinda 75123, East Kalimantan, Indonesia \\ ${ }^{3}$ Research Institute for Natural Resource Conservation Technology. Jl. Soekarno Hatta Km.38, Sungai Merdeka, Samboja, Kutai Kartanegara 75271, East \\ Kalimantan, Indonesia
}

Manuscript received: 4 January 2020. Revision accepted: 13 April 2020.

\begin{abstract}
Kristiningrum R, Lahjie AM, Masjaya, Yusuf S, Ruslim Y, Ma'ruf A. 2020. Fauna diversity, production potential and total economic value of mangrove ecosystems in Mentawir Village, East Kalimantan, Indonesia. Biodiversitas 21: 1940-1953. Mangroves play important role in life. The benefits of the mangrove ecosystem consist of ecological and socio-economic values. However, it is a challenge to discern how the mangrove ecosystem provides a comprehensive economic value. This research is aimed to analyze the Total Economic Value (TEV) of mangrove ecosystems in Mentawir Village, North Penajam Paser District, East Kalimantan Province. This aim will be achieved by conducting fauna inventory, analysis of mangrove wood production potential, social-economic interviews, and infrastructure cost analysis as the inputs to calculate four elements (i.e. Direct Use Value, Indirect Use Value, Option Value, and Existence Value) to sum up the TEV. The research used a mixed-method combining both qualitative and quantitative methods. Fauna inventory was conducted using boat survey method and interviews with local fishermen. Data on mangrove wood production was obtained using the systematic random sampling method by establishing two plots with an area of one hectare for each plot to calculate mean annual increment (MAI) and current annual increment (CAI). The economic value of the mangrove ecosystem was calculated using market price values, replacement costs, and the Contingent Valuation Method (CVM). The results of fauna inventory consisted of 3 species of mammals, 1 species of reptile, 16 species of birds, 25 types of fish, 8 species of crustaceans, and 7 species of mollusks. The economic valuation resulted in the contribution of direct use value with $39.56 \%$ in the form of wood $(94,875,000,000$ IDR) and fishery products $(103,500,000,000 \mathrm{IDR})$; indirect use value with $53.47 \%$ in the form of breakwater $(38,028,881,407$ IDR), abrasion resistance $(218,549,528,110$ IDR), and carbon sequestration $(11,580,313,067)$; option value with $6.92 \%$ in the form of biodiversity (34,690,085,038 IDR); and existence value with $0.05 \%$ (241,500,000 IDR). All these resulted in the total economic value (TEV) of the mangrove ecosystem in Mentawir Village of 501,465,307,621 IDR. Therefore, this value can be the basis for policymakers in managing natural resources so that the ecosystem is more protected and sustainable, and can continue to provide environmental services for the welfare of the community.
\end{abstract}

Keywords: Biodiversity, economic valuation, fauna, growth, mangrove, Mentawir

\section{INTRODUCTION}

Mangrove is an evergreen, salt-tolerant plant community that grows in inter-tidal coastal zones of the tropical and subtropical regions of the world (FAO 2008). Mangrove ecosystems are ecologically important for many fauna species as they are rich in food resources and consist of many different vegetation structures. They serve as ideal foraging and nursery grounds for a wide array of species such as birds, mammals, reptiles, fish, and aquatic invertebrates (Zakarian and Rajpar 2015). Mangrove ecosystems also serve as buffer zones and provide protection from coastline erosion (Lundquist et al. 2017).

Besides having an ecological function, the mangrove ecosystem also has considerable economic benefits. Mangrove ecosystems contribute significantly to increasing community income as well as supporting regional and state economy. Goods produced from mangrove ecosystems include firewood, building materials, fertilizers, paper raw materials, food ingredients, beverages, household appliances, candles, honey, recreation, fishing grounds, and more (Walters et al. 2008; Saenger 2011; Oktawati and Sulistianto 2015). Nonetheless, despite the high importance of mangrove ecosystems, they are often regarded as public property resources that can be used by anyone without regard to their sustainability aspects. This view triggers over-utilization of mangrove resources, causing the depletion of such resources and the degradation of the ecosystems in providing environmental services (Darmawan 2015).

Wijaya (2018) states that one of the leading research themes in 2019-2023 will be the quantification and valuation of coastal ecosystem services. Coastal and marine ecosystems use many estimates of ecosystem service assessments (Vegh et al. 2014). Economic valuation is an attempt to provide quantitative value to goods and services produced by natural resources and the environment, both on the basis of market value and non-market value. Economic valuation is defined as a process of attaching monetary value or price to non-marketed environmental goods and services (Rao 2000). Economic valuation plays 
an important role in decision making although it is often fraught with limitations. The economic value is generally defined as a measurement of the maximum number of people wanting to sacrifice goods and services to obtain other goods and services (Fauzi and Anna 2005). This estimate reflects various economic valuation methods. Barbier et al. (2011) state that some of these economic valuation methods depend on the value of ecosystem services and some depend on the non-market approach. Ecosystem services are said to be important if they can be valued or quantified in monetary terms.

One way to conduct a monetary valuation of ecosystem services is to use a comprehensive assessment from a total economic valuation (TEV) method. TEV considers the benefit of transfer as an important platform for appreciating and analyzing sustainability values in the decision-making process. The TEV is valued by revealed preference or stated preference. The TEV tries to adopt entirely marginal values for ecosystem services, according to the additional values derived from the total estimation of willingness to pay and willingness to accept some environmental commodities. TEV is the combination of direct, indirect, option, existence and bequest value, altruistic value, quasi option value (which are based on use value), and non-use ecosystem values of services (Price 2007). The TEV of world mangrove ecosystem services is around USD 200 billion (Vo et al. 2012).

Balikpapan Bay is a strategic port in the province of East Kalimantan. As a consequence of development in Balikpapan Bay, it caused damage to the mangrove ecosystems of about $47.6 \%$ and a decrease in the area of mangrove forests by around $12.5 \%$ in the last 15 years (Lahjie et al. 2019). Warsidi (2017) stated that mangrove forests in the Balikpapan Bay area consist of primary mangrove forests and secondary mangrove forests, which are generally dominated by Rhizophora apiculata species. Given the low appreciation of the local community for the potential of mangrove forests as an economic asset, it is necessary to do an economic valuation of the magnitude and benefits of mangrove forests. This research is aimed to analyze the Total Economic Value (TEV) of mangrove ecosystems in Mentawir Village, Penajam Paser Utara District, East Kalimantan Province. This aim will be achieved by conducting fauna inventory, analysis on mangrove wood production, social-economic interviews, and infrastructure cost analysis as the inputs to calculate four elements (i.e. Direct Use Value, Indirect Use Value, Option Use Value and Existence Use Value) to sum up the TEV.

\section{MATERIALS AND METHODS}

\section{Study area and periods}

This study was conducted in Mentawir Village, North Penajam Paser District, East Kalimantan Province (Figure 1). The rationale of selecting this village is the utilization of mangrove ecosystems that is still very natural and as one of the mangrove tourism villages in East Kalimantan. The research period lasted for four months from November 2019 to March 2020.

\section{Data collection}

The research used a mixed-method by combining qualitative and quantitative methods (Masrizal 2011). Observations of species of fauna were conducted using boat survey along $2.5 \mathrm{~km}$ with the track following the river flow (Salter and MacKenzie 1985; Atmoko et al. 2007; Ridzwan Ali et al. 2009; Atmoko et al. 2011). The total distance of exploration during the study was $13.3 \mathrm{~km}$, including the Mentawir River, Tiram Tambun River, Penyanggulan River, Sekambing River, and Loop River. Site identification and recognition including river names and tributaries were based on information from local communities. Observations were started in the morning at 6: 30 am until $2 \mathrm{pm}$. The aquatic faunas were caught using fishing rods and cast nets while aquatic invertebrates were collected via swap nets. We also gathered data from fish catches by local fishermen.

Data collection on mangroves were conducted using systematic random sampling by establishing two plots, namely Plot 1 (mangrove stands with an estimated wood volume of around $100 \mathrm{~m}^{3}$ ) and Plot 2 (around $60 \mathrm{~m}^{3}$ ). Each plot has an extent of one hectare in which four sub-plots with size of $2500 \mathrm{~m}^{2}(50 \mathrm{~m} \times 50 \mathrm{~m})$. 4 times with data collection methods in the form of systematic random sampling.

Social-economic data was collected using purposive sampling (Sugiyono 2015) by conducting direct interviews with selected fishermen and communities around the mangrove.

\section{Data analysis}

Analysis of mangrove wood production

This study used Microsoft Office Excel to perform calculations and generate graphs. Analysis of mangrove wood was done by calculating the total volume of standing stock as follows:

$$
\mathrm{V}=\frac{1}{4} \Pi d^{2} h t f
$$

Where: V: standing volume, $\mathrm{d}$ : diameter at breast height, h: branch free height, f: form factor

We also analyzed the growth increment of mangrove. The increment is an increase in tree dimension growth (height, diameter, base area, and volume) associated with tree age or a particular period. Based on the measurement period, there are mean annual increment (MAI) and current annual increment (CAI) (Van Gardingen et al. 2003), and formulated as follows:

$$
\mathrm{MAI}=\frac{V_{t}}{t}
$$

Where: MAI: mean annual increment, $\mathrm{Vt}$ : total standing volume at age $\mathrm{t}, \mathrm{t}$ : tree age.

$$
\mathrm{CAI}=\frac{V_{t}-V_{t-1}}{T}
$$

Where: CAI: current annual increment, Vt: total standing volume at age $\mathrm{t}, \mathrm{Vt}-1$ : total standing volume at age $\mathrm{t}-1, \mathrm{~T}$ : time interval between each measurement age. 

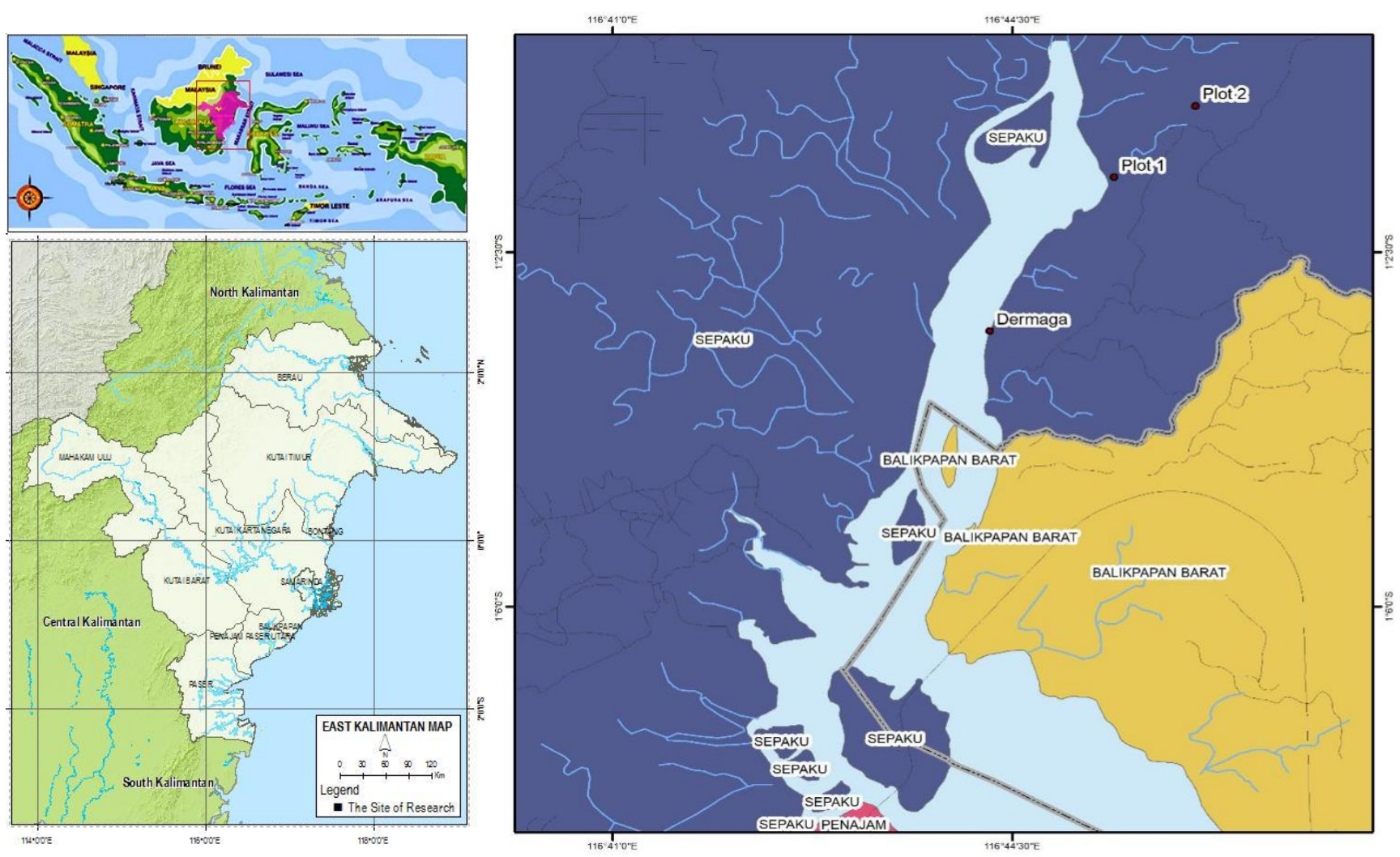

Figure 1. Research location in Mentawir Village, Sepaku Sub-district, North Penajam Paser District, East Kalimantan, Indonesia

The relationships between variables were analyzed using simple linear regression to determine the coefficient of regression determination $\left(\mathrm{R}^{2}\right)$.

\section{Analysis of total economic value}

The analytical methods related to the calculation of total economic value of mangrove ecosystems in Mentawir Village based on:

Direct use-value. The direct use-value is the economic or social value of the goods or benefits derived from the services provided by an ecosystem that can be used directly by an economic agent. Determination of the types of direct benefits can be seen based on the market price approach for marketable goods and services such as fisheries productivity. Measurement of direct use value based on market prices according to Tuwo (2011) can be formulated as follows:

$$
\mathrm{MLi}=(\mathrm{HPI} \times \mathrm{Pi})-\mathrm{Bpi}
$$

Where: MLi: Direct use value of commodity i (IDR yr ${ }^{1}$ ), HPI: Commodity Market Price (IDR. $\mathrm{Kg}^{-1}$ ), Pi: Commodity Production i $\left(\mathrm{Kg} \mathrm{yr}^{-1}\right)$, BPI: Operational costs (IDR), i: type of commodity (for example: shrimp, fish, crab, etc.),

So that the value of the direct benefits of the mangrove ecosystem can be formulated as follows:

$$
\mathrm{ML}=\mathrm{ML} 1+\mathrm{ML} 2
$$

Where: ML: Direct benefits, ML1: Direct benefits of wood, ML2: Direct benefits of fisheries

Indirect use-value. Indirect use-value is the value of utilization based on an indirect function of the existence of mangrove ecosystems, such as a breakwater, an abrasion restraint, and carbon sequestration. The formulation of the calculation of benefits as a breakwater, according to Kurniawati and Pangaribowo (2017), is as follows:

$$
\mathrm{MTL}=\mathrm{PGP} \times \mathrm{B}
$$

Where: MTL: Indirect benefits (IDR $\left.\mathrm{yr}^{-1}\right)$, PGP: coastline length (m), B: standard concrete cost (IDR)

The standard cost of concrete breakwaters was referred to the Regulation of the Minister of Public Work and Housing No. 28 of 2016. The cost to make a breakwater building with a length of $150 \mathrm{~m}$, width $20 \mathrm{~m}$ and height $5 \mathrm{~m}$ with a durability of 20 years requires $2,921,147,000$ IDR $\mathrm{m}^{3}$ or equal to $194,743 \mathrm{IDR} \mathrm{m}^{-1}$. To accommodate inflation, the cost in 2016 was updated to 2019 with the formula according to (Osmaleli 2013) and formulated as follows:

$$
\mathrm{V}_{2019}=\mathrm{V}_{2016}(1+\mathrm{i})^{\mathrm{n}}
$$

Where: V: value in respective year (IDR), i: interest rate $(6.5 \%), \mathrm{n}$ : amount of time (years)

The indirect value of mangrove forests as an abrasion barrier can be estimated using replacement costs or the cost 
of building breakwater structures (Marhayana et al. 2011; Anissa 2012; Samsul 2013). The cost for building a breakwater with a size of $70 \mathrm{~cm} \times 300 \mathrm{~cm} \times 150 \mathrm{~cm}$ with a durability of 10 years according to Fidyansari and Hastuty (2016) requires a fee of $1,272.38 \mathrm{IDR} \mathrm{m}^{-3}$. For the length of 1 meter, the building uses $3 \mathrm{~m}^{3}$ of the mixture of the construction material of the breakwater so that it costs

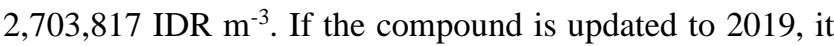

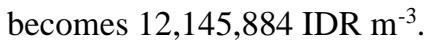

The formulation of the calculation of benefits as a carbon sink according to Prayogi et al. (2016) is multiplying the amount of carbon with the selling price of carbon. Where the carbon price is $7 \mathrm{USD}^{-1}$, if it is compounded to 2019, the carbon value will be 8.5 USD ton $^{-1}$.

Option use-value. The assessment of the benefits of choice refers to the biodiversity value of the mangrove ecosystem. The value used referred to Ruitenbeek (1992) in Bintuni Bay, West Irian, which is US \$ $15 /$ ha/year. This value is updated to 2019 to accommodate interest rate using the following formula (Osmaleli 2013):

$$
\mathrm{V}_{2019}=\mathrm{V}_{1992}(1+\mathrm{i})^{\mathrm{n}}
$$

Where: V: biodiversity value (IDR), i: interest rate (17\%), n: amount of time (years)

The compound values that have been obtained need to be adjusted to the purchasing power and prices in the Mentawir Village so that the calculation results obtained are more accurate using the formula below:

\section{$\mathrm{NP}=\mathrm{V} \times \mathrm{M}$ x Dollar Exchange}

Where: NP: total value of mangrove biodiversity in Mentawir Village in 2019, V: biodiversity value of mangrove ecosystems in Mentawir Village that has been compounded, M: Area of mangrove ecosystem (ha)

Existence use-value. Existence Use Value is the benefits felt by the community related to the existence of mangrove ecosystems. The calculation of economic valuation uses the contingent valuation method (CVM), which is the willingness to pay (WTP) to calculate the value of wood and willingness to accept (WTA) to calculate catches. If the WTP and WTA values are known, then the balance of the WTP and WTA can be calculated. According to Halkos and Galani (2013); Malik et al. (2015); Wahyuni et al. (2014); Widiastuti et al. (2016); Wuthiya (2016); Sina et al. (2017), value assessment of WTP for services provided by coastal ecosystems is usually done to provide value appreciation for the existence of coastal ecosystems such as mangroves, reefs coral, seagrass and fish resources (Rizal and Dewanti 2017). Therefore, Hanley and Spash (1993) state that WTP is a value of potential uses of natural resources and environmental services. According to Kristiningrum et al. (2019), CVM is a survey-based approach that involves developing a hypothetical market by directly asking an individual to state his or her willingness to pay (WTP) for the environmental services provided in a particular location and willingness to accept (WTA) as the compensation for any damages. In this research, Mitchell and Carson 1989; Turner and Pearce 1990; and Suprapto 2016, CVM were used for valuing mangrove ecosystem and it aims to assess the willingness to pay of communities for the mangrove ecosystem. The marginal willingness to pay was calculated by the differences in the coefficients between the two attribute levels. Households were asked about how much they would pay for a given service level, describing at which level they were willing to contribute to experience a transformation of something (Kamaludin et al. 2018). This study refers to the research of Kristiningrum et al. (2019) that the calculation of WTP and WTA was derived from the calculation of the total income from mangrove wood production and yields from fisheries catches. Where both form a point of intersection called the margin (balance). However, in this research, the approaching model with WTP of wood was assumed as the ability of the community to pay for natural and environmental services in mangrove conservation activities whose value is obtained from the mangrove wood. While the WTA of fish catch approach model is assumed as a willingness from the community to receive compensation (in the form of funds) derived from fisheries catches. The value of the margin (profit) from both the WTP and the WTA was made as to the balance value and calculated as follows:

$$
\mathrm{AW}=\frac{T W}{t}
$$

Where: AW: average willingness, TW: total willingness at age $\mathrm{t}, \mathrm{t}$ : age

$$
\mathrm{MW}=\frac{W_{t}-W_{t-1}}{T}
$$

Where: MW: marginal willingness, $\mathrm{Wt}$ : total willingness at age $\mathrm{t}, \mathrm{Wt}-1$ : total willingness at age $\mathrm{t}-1, \mathrm{~T}$ : time interval between each measurement age, both to pay and to accept (MWTP or MWTA) i.e Marginal willingness to pay (MWTP) from wood and marginal willingness to accept from a catch.

Total economic value. This value is the sum of all the values of direct, indirect, choice and existence. The formulations according to Price (2007) and Vo et al. (2012) are as follows:

$$
\mathrm{NET}=\mathrm{ML}+\mathrm{MTL}+\mathrm{NP}+\mathrm{NE}
$$

Where: NET: Total economic value, ML: Direct usevalue, MTL: Indirect use-value, NP: Option use-value, NE: existence use value

\section{RESULTS AND DISCUSSION}

\section{Diversity of fauna species of mangrove ecosystems}

The mangrove ecosystem in the Mentawir Village is part of the Balikpapan Bay mangrove ecosystem. In addition to the beauty of the natural scenery, the mangrove ecosystem in Mentawir Village has a rich biodiversity in 
the form of mangrove species. According to Kristiningrum et al. (2019), there are 12 species of mangroves in Mentawir Village, while according to Warsidi (2017) they found as many as 20 species of mangroves in Balikpapan Bay. These results are higher than the research by Oktawati and Sulistianto (2013) in Kariangau village, Balikpapan Municipality, which only found 4 species of mangroves. Besides biodiversity, it turns out that mangrove ecosystems also have a diversity of protected wildlife such as Bekantan (Nasalis larvatus), sea dolphins (Orcaella brevirostris), dugongs (Dugong dugon), green turtles (Chelonia mydas), and other exotic animals (Hutapea 2016). According to Lhota (2010), Balikpapan Bay and the surrounding mangrove forests have almost 300 species of birds including endangered species such as Storm storks (Ciconia stormi), vulnerable birds such as Tontong storks (Leptoptilos javanicus), and a small fish eagle (Ichthyophaga humilis) which is near threatened. Mammals that live in the area include various types of bats, squirrels, weasels, and otters, while the types of reptiles present also have some endangered species, namely the green turtle (Chelonia mydas).

Based on the identification, the species of fauna that exist in the mangrove ecosystem of Mentawir Village include 3 species of mammals, 1 species of reptile, 16 species of birds, 25 species of fish, 8 species of crustaceans, and 7 species of mollusks (Figure 2, 3, 4, 5, and 6). The species of mammals in the Mentawir mangrove ecosystem include Nasalis larvatus, Macaca fascicularis, and Tupaia minor, and the reptile species is Cuora amboinensis (Figure 2).

According to Lhota (2010), Balikpapan Bay and the surrounding mangrove forests have almost 300 species of birds. Based on the research that we did in Mentawir, we identified 16 species of birds illustrated in Figure 3. Sari (2012) found as many as 12 species of birds, of which three overlapped with those in the mangrove ecosystem of Mentawir Village: Haliastur indus, Egretta eulophotes, and Pelargopsis capensis at Bina Ovivipari Semesta Company and its surroundings in West Kalimantan Province.

The 8 species of crustaceans found in the Mentawir mangrove ecosystem can be seen in Figure 4. The 25 species of fish found in the Mentawir mangrove ecosystem can be seen in Figure 5. There are also 7 different species of mollusks as shown in Figure 6.

The high diversity of mammal, reptile, avian, fish, and aquatic invertebrate species illustrates that the mangrove ecosystem of Mentawir Village has attracted a wide array of fauna species. It has been stated that mangrove habitats may harbor a wide range of animals such as birds, mammals, reptiles, fishes, and aquatic invertebrates. According to Zakaria and Rajpar (2015), the presence of a higher diversity of fauna could be due to the habitat's pristine condition (i.e., no disturbance), complex vegetation structure and composition, the availability and richness of food resources such as fish, mollusks and crustaceans, and low predation risk. The vegetation structure and composition, occurrence of mudflats, and richness of food resources are the major driving factors that influence the distribution and diversity of animals directly or indirectly. Vegetation heterogeneity, the abundance of food resources, and habitat diversity may increase avian richness and diversity, i.e. they provide suitable foraging and rearing grounds, and protection from harsh weather and predators.

The high number of fish species suggests that the mangrove ecosystem of Mentawir Village areas serves as a nursery ground for various juvenile fish communities. This area is likely rich in invertebrate assemblages such as crustaceans (crabs, prawns, and shrimps) and mollusks (Nerita lineata, Cerithidea djadjariensis, Chicoreus capucinus, Crassostrea spp, Anadara granosa, Placuna placenta, and Telecopium telescopium). In addition, the extensive root systems of mangroves create habitat heterogeneity and complexity (Correa and Oliveria 2008, Wang et al. 2008), offering suitable foraging sites for juvenile fish and protecting them from predators by reducing their visibility (Zakaria and Rajpar 2015). Habitat heterogeneity and complexity is a major factor that influences fauna diversity and distribution.

In addition to fish species, it turns out that birds also dominate the mangrove ecosystem of Mentawir Village. These bird species utilize the area to fulfill their daily requirements of habitat, water, food, and protection from predators and harsh weather. Therefore, the mangrove ecosystem must be protected in a sustainable way to protect its diverse aquatic and terrestrial fauna species for future generations.

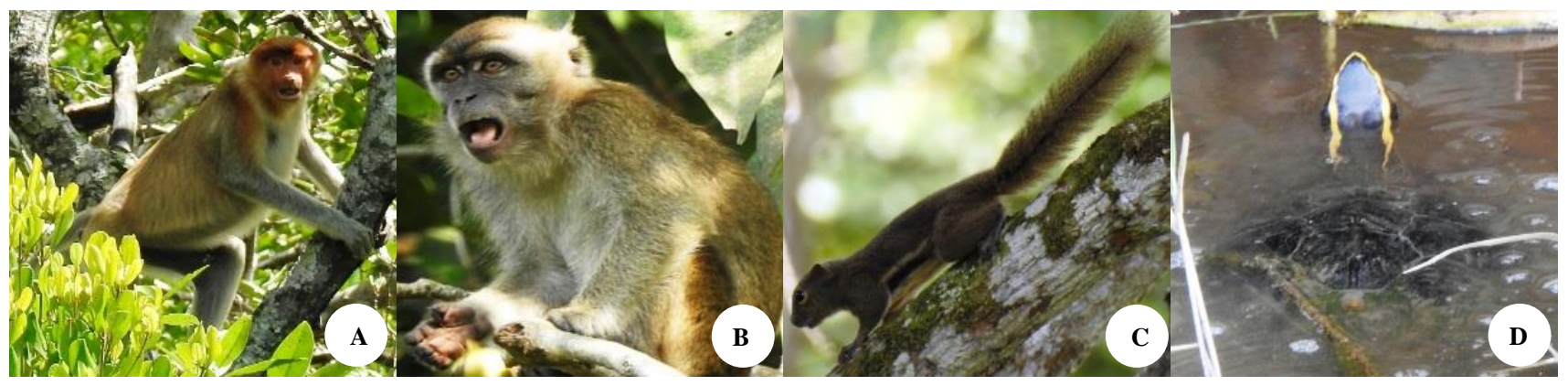

Figure 2. Species of mammals and reptiles in the Mentawir mangrove ecosystem, East Kalimantan, Indonesia. A. Nasalis larvatus; B. Macaca fascicularis; C. Tupaia minor; D. Cuora amboinensis 


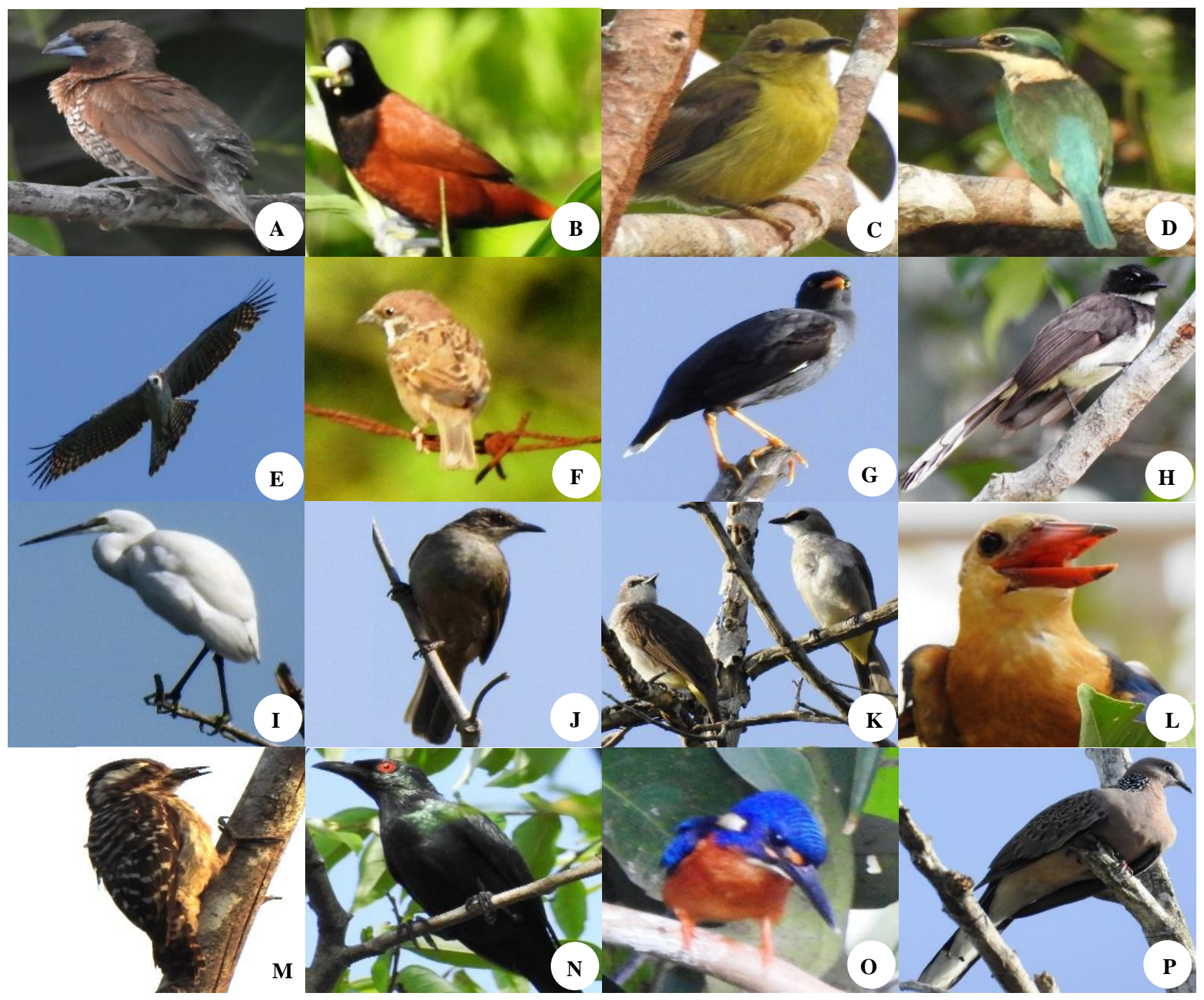

Figure 3. Species of Aves/birds in the mangrove ecosystem of Mentawir Village, East Kalimantan, Indonesia. A. Lonchura fuscans female; B. Lonchura fuscans male; C. Dicaeum sp.; D. Todirhamphus sanctus; E. Haliastur indus; F. Passer montanus; G. Acridotheres javanicus; H. Rhipidura javanicus; I. Egretta eulophotes; J. Pycnonotus plumosus; K. Pycnonotus goiovier; L. Pelargopsis capensis; M. Dendrocopus canicapillus; N. Aplonis panayensis; O. Alcedo meninting; P. Streptopelia chinensis

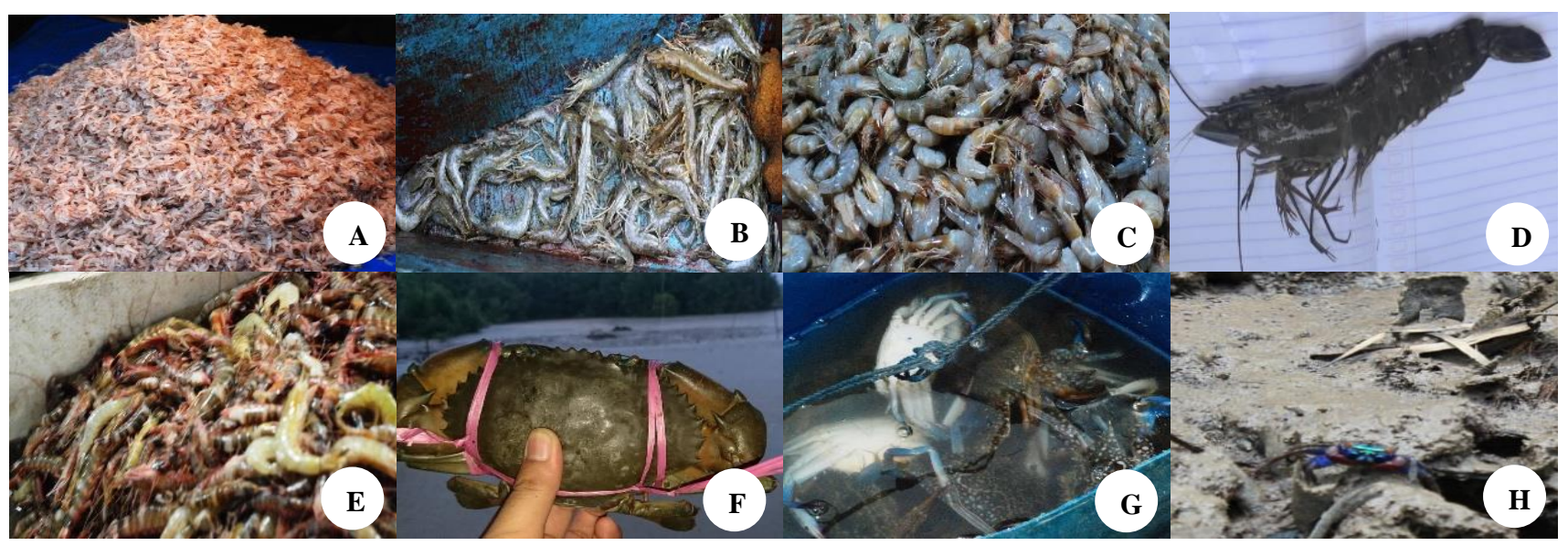

Figure 4. Species of crustaceans in the mangrove ecosystem of Mentawir Village, East Kalimantan, Indonesia. A. Mysis relicta, B. Alpheus sp., C. Penaeus merguiensis, D. Penaeus monodon, E. Penaeus spp., F. Scylla serrata, G. Portunus pelagicus, H. Episeserma sp. 


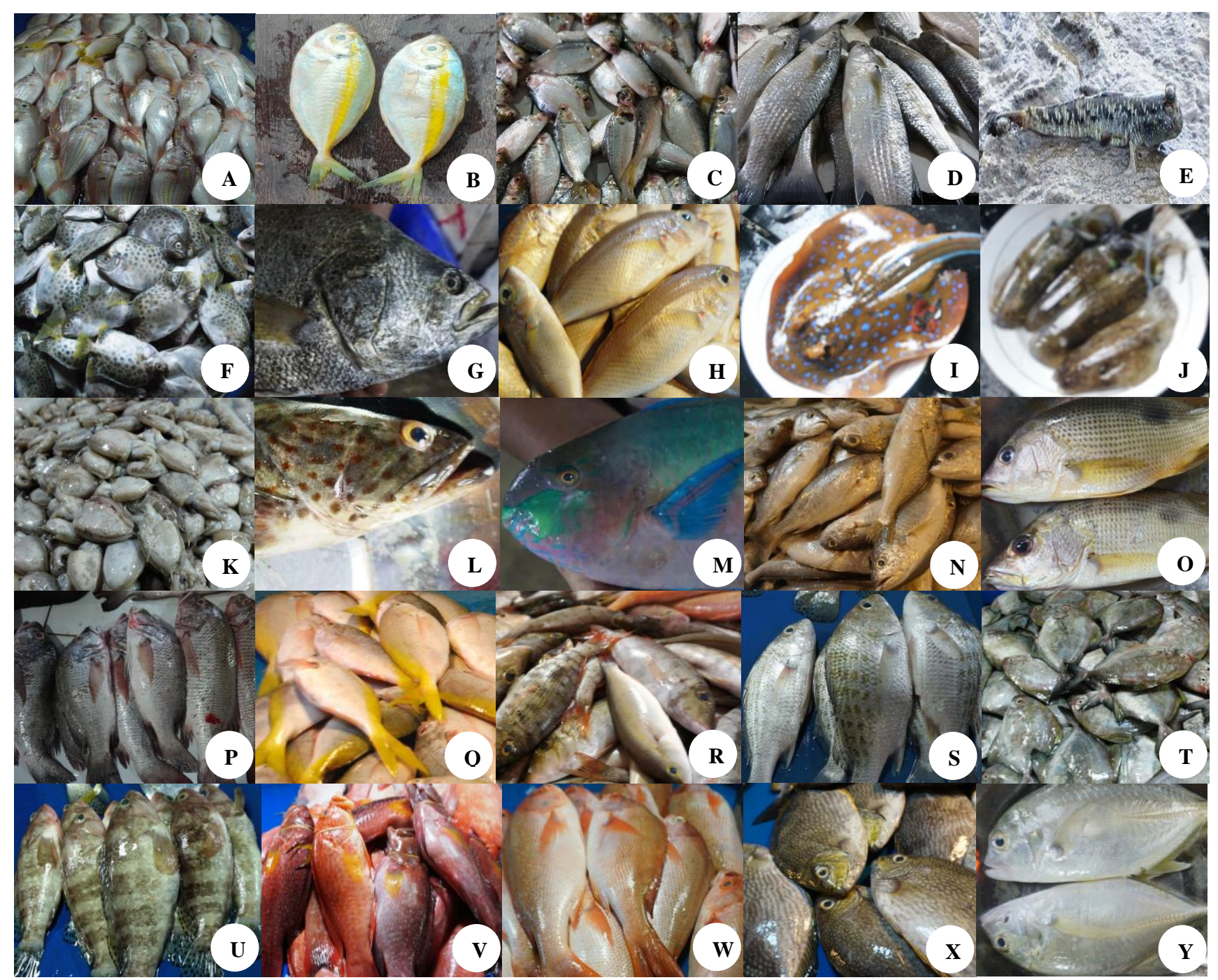

Figure 5. Species of fishes in the mangrove ecosystem of Mentawir Village, East Kalimantan, Indonesia. A. Nemipterus sp., B. Selaroides leptolepis, C. Selaroides sp., D. Tade mullet, E. Periopthalmus sp., F. Scatophagidae, G. Micropterus salmoides, H. Nemipterus sp., I. Dasyatis sp., J. Cephalopoda sp., K. Sepiida, L. Epinephelus bleekeri, M. Labroide, N. Tenualosa ilisha, O. Lutjanus mahogoni, P. Lutjanus argentimaculatus, Q. Ocyurus chrysurus, R. Lutjanus griseus, S. Lates calcarifer, T. Parastromateus niger, U. Moluccan goatfish, V. Plectropomus maculatus, W. Plectropomus maculatus, X. Orange spotted spinefoot, Y. Caranx ignobilis.
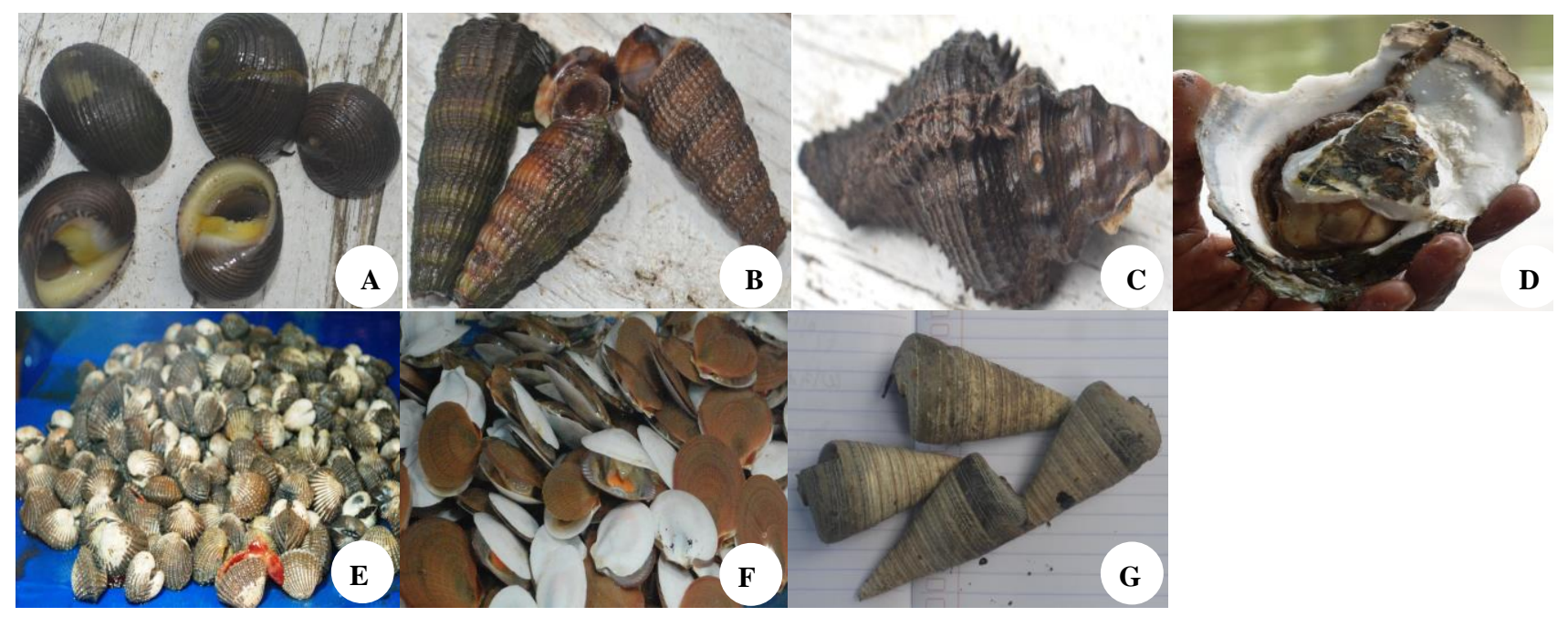

Figure 6. Species of molluscs fauna in the mangrove ecosystem of Mentawir Village, East Kalimantan, Indonesia. A. Nerita lineata, B. Cerithidea djadjariensis, C. Chicoreus capucinus, D. Crassostrea spp, E. Anadara granosa, F. Placuna placenta, G. Telecopium telescopium. 


\section{Identification of potential and types of utilization of mangrove ecosystems}

The identification process was performed in order to discover the various types/forms of utilization of the mangrove ecosystems in the study location. This process was completed before the quantification or assessment of the benefits. Identification of direct use value was accomplished by asking the community to provide options related to various direct uses of the mangrove ecosystem. The types of direct use of mangrove ecosystems in various regions are usually different, so by providing options or a choice of answers, it is expected to help respondents to answer in accordance with individual knowledge related to the benefits derived from the existence of mangrove forest ecosystems in their area. The answer options or choices of the types of direct use of mangrove forests in Mentawir Village included wood resources, fisheries, tourist attractions, mangrove processed products, as well as other answer choices from respondents outside the options offered. Wood, shrimp, shellfish, mullet fish, crabs, mangrove syrup, sticky cake (dodol) from mangrove products, and mangrove powder were examples of direct use. However, the calculation of the direct use value of using mangroves only calculates the value of wood and fish. Indirect use value includes breakwaters, abrasion restraints, and carbon storage, as well as non-use value in the form of biodiversity. The different forms of utilization are evidence of the diversity of ecosystem benefits in each region.

\section{Production potential of mangrove wood}

The results of data collection on Plot 1 showed that there were 466 trees with ages ranged from 24 to 54 years, diameter ranged from 15 to $35 \mathrm{~cm}$ (average of $25 \mathrm{~cm}$ ), and height ranged from 6 to 11 meters (average of $8.1 \mathrm{~m}$ ). The maximum wood potential of mangroves was achieved at the age of 45 years with a total volume of $12.2 \mathrm{~m}^{3} \mathrm{ha}^{-1}$, with a maximum increment of MAI and CAI respectively at 0.27 and $0.25 \mathrm{~m}^{3} \mathrm{ha}^{-1} \mathrm{yr}^{-1}$. Within the one hectare of Plot 1 , there are 466 trees with a total volume of $102.1 \mathrm{~m}^{3} \mathrm{ha}^{-1}$ and MAI and CAI increments respectively at 2.51 and 3.45 $\mathrm{m}^{3} \mathrm{ha}^{-1} \mathrm{yr}^{-1}$. The results of analysis of wood production potential can be seen in Table 1 .

The optimal mangrove increment is achieved at the age of 45 years when MAI reached the peak, and after the age of 45 years, the MAI increment has decreased from 0.27 to 0.25. This means that the timber cutting rotation for mangrove in Plot 1 is 45 years is followed by the biological cycle of the tree stand, in which the stand will be harvested when MAI is equal to CAI. The graphical relationship between MAI and CAI can be seen in Figure 7 below.

At Plot 2, the results of analysis showed that the maximum potential of mangroves was achieved at the age of 39 years with a total volume of $7.6 \mathrm{~m}^{3} \mathrm{ha}^{-1}$, with a maximum increment of MAI and CAI respectively in of 0.20 and $0.21 \mathrm{~m}^{3} \mathrm{ha}^{-1}$ year $^{-1}$. In one hectare of Plot 2, there were 604 trees with a total volume of $62.9 \mathrm{~m}^{3} \mathrm{ha}^{-1}$ and the increment of MAI and CAI are respectively at 1.82 and
$2.26 \mathrm{~m}^{3} \mathrm{ha}^{-1}$ year ${ }^{-1}$. The results of the mangrove stand analysis in Plot 2 can be seen in Table 2 .

As can be seen in Figure 8, the optimal mangrove increment is achieved at the age of 39 years when MAI reached the peak, and after this age, mangrove the MAI has decreased from 0.20 to 0.18 . This means that the timber cutting rotation of mangrove at Plot 2 is 39 years.

According to Dinga (2014), Muliadi et al. (2017), Winarni et al. (2017) and Kristiningrum et al. (2019), the graphs in Figures 7 and 8 exhibit certain characteristics, as follow: CAI curve rapidly reached the peak and from there declined immediately, whereas the MAI curve climbed and declined slowly. From the graphical results in Figures 7 and 8 , it was revealed that this was the beginning, MAI was lower than CAI, and CAI reached the peak preceding MAI. After reaching the peak, CAI declined and at a particular point intersected with MAI. At Plot 1, the intersection point of MAI and CAI occurred at the age of 48 years, while that of Plot 2 occurs at the age of 42 years.

After the intersection point, both MAI and CAI declined, indicating a decreasing trend in the volume increment. At Plot 1, the mean annual standing volume of increment of mangrove trees has reached the maximum at the age of 45 years, indicating that the maximum timber production potential has been attained and the tree was ready to be cut down. At plot 2, this occurs at the age of 39 .

There is strong relationship between age and annual increment, either in the form of MAI and CAI. A simple linear regression test using polynomial trend shows the $\mathrm{R}^{2}$ value is $98 \%$ for the relationship between age and MAI in Plots 1 and 2. For the relationship between age and CAI, the $\mathrm{R}^{2}$ value is $87 \%$ and $86 \%$ for Plot 1 and Plot 2, respectively.

Mangrove in 1 hectare is respectively at 2.51 and 3.45 $\mathrm{m}^{3} \mathrm{ha}^{-1} \mathrm{yr}^{-1}$. This is in line with research conducted by Kristiningrum et al. (2019), that the highest growth increment of mangrove wood production was reached at the age of 42 years, and the highest value of MAI was 2.97 $\mathrm{m}^{3} \mathrm{ha}^{-1} \mathrm{yr}^{-1}$. This is supported by a simple linear regression test with the type of polynomial on MAI which has an $\mathrm{R}^{2}$ of $98 \%$. This value means that there is a close relationship between age and MAI increment of $98 \%$ and $2 \%$ influenced by other factors. Whereas the CAI has an $\mathrm{R}^{2}$ of $87 \%$. This value means that there is a close relationship between age and CAI increment of $87 \%$ and $13 \%$ influenced by other factors.

The results of data collection on plot two where the diameter of the log and also the height of the mangrove tree obtained indicate that the maximum potential of mangroves was achieved at the age of 39 years with a total volume of $7.6 \mathrm{~m}^{3} \mathrm{ha}^{-1}$, with a maximum increment of MAI and CAI respectively in of 0.20 and $0.21 \mathrm{~m}^{3} \mathrm{ha}^{-1}$ year $^{-1}$. Where in 1 hectare there are 604 trees with a total volume of $62.9 \mathrm{~m}^{3}$ $\mathrm{ha}^{-1}$ and the increment of MAI and CAI are respectively at 1.82 and $2.26 \mathrm{~m}^{3} \mathrm{ha}^{-1}$ year $^{-1}$. The results of the mangrove stand analysis in plot two can be seen in Table 2 . 
Table 1. Analysis of production potential of mangrove wood at Plot 1

\begin{tabular}{lllllllll}
\hline No. & $\mathbf{n}$ & Age & $\mathbf{d}$ & $\mathbf{h}$ & $\mathbf{f}$ & TV & MAI & CAI \\
\hline 1 & 56 & 24 & 15 & 4.0 & 0.81 & 3.2 & 0.13 & \\
2 & 50 & 27 & 17 & 4.5 & 0.80 & 4.1 & 0.15 & 0.29 \\
3 & 50 & 30 & 19 & 5.0 & 0.77 & 5.5 & 0.18 & 0.46 \\
4 & 48 & 33 & 21 & 5.5 & 0.76 & 6.9 & 0.21 & 0.50 \\
5 & 48 & 36 & 23 & 6.0 & 0.73 & 8.7 & 0.24 & 0.59 \\
6 & 48 & 39 & 25 & 6.5 & 0.66 & 10.1 & 0.26 & 0.46 \\
7 & 44 & 42 & 27 & 7.0 & 0.65 & 11.5 & 0.27 & 0.45 \\
$\mathbf{8}$ & $\mathbf{3 8}$ & $\mathbf{4 5}$ & $\mathbf{2 9}$ & $\mathbf{7 . 6}$ & $\mathbf{0 . 6 4}$ & $\mathbf{1 2 . 2}$ & $\mathbf{0 . 2 7}$ & $\mathbf{0 . 2 5}$ \\
9 & 32 & 48 & 31 & 8.5 & 0.63 & 12.9 & 0.27 & 0.24 \\
10 & 28 & 51 & 33 & 9.7 & 0.58 & 13.5 & 0.26 & 0.18 \\
11 & 24 & 54 & 35 & 10.3 & 0.57 & 13.5 & 0.25 & 0.03 \\
Total & $\mathbf{4 6 6}$ & & & & & $\mathbf{1 0 2 . 1}$ & $\mathbf{2 . 5 1}$ & $\mathbf{3 . 4 5}$ \\
\hline
\end{tabular}

Note: $\mathrm{n}$ : number of trees $\left(\right.$ tree $\left.\mathrm{ha}^{-1}\right)$, d: tree diameter $(\mathrm{cm}), \mathrm{h}$ : branch tree height $(\mathrm{m}), \mathrm{f}$ : tree form factor, TV: total volume $\left(\mathrm{m}^{3}\right.$ $\left.\mathrm{ha}^{-1}\right)$, MAI: mean annual increment $\left(\mathrm{m}^{3} \mathrm{ha}^{-1} \mathrm{yr}^{-1}\right)$, CAI: current annual increment $\left(\mathrm{m}^{3} \mathrm{ha}^{-1} \mathrm{yr}^{-1}\right)$

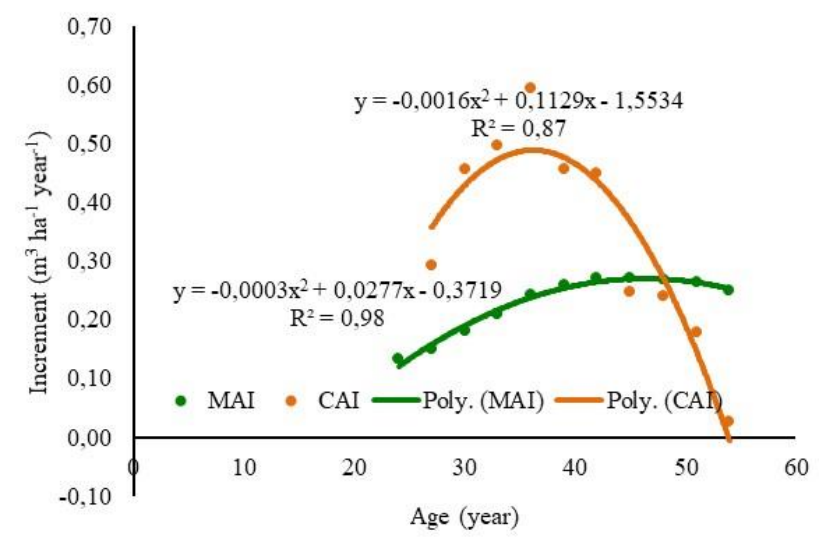

Figure 7. Standing volume increment of mangrove at Plot 1

Based on Table 2 it can be explained that in 1 hectare there are 604 mangrove trees in plot two with a diameter of mangrove at the age of 18 to 48 years of 11 to $31 \mathrm{~cm}$ with an average diameter of $21 \mathrm{~cm}$. While the height is 2.2 to 7.3 meters with an average height of $4.7 \mathrm{~m}$. With a total volume of $62.9 \mathrm{~m}^{3} \mathrm{ha}^{-1}$ and increment of 1.82 and $2.26 \mathrm{~m}^{3}$ $\mathrm{ha}^{-1} \mathrm{yr}^{-1}$. The optimal mangrove increment is achieved at the age of 39 years. After the age of 39 years, mangrove increment has decreased from 0.20 to 0.18 . This means that the timber cutting rotation is followed by the biological cycle of the tree stand, in which the stand will be harvested when MAI is equal to CAI. As for graphically, the relationship between MAI and CAI can be seen in Figure 8.

The intersection point of MAI and CAI occurred at the age of 42 years. After the intersection point, both MAI and CAI declined, indicating a decreasing trend in the volume increment. At the age of 42 years, the mean annual standing volume increment of mangrove tree has reached the maximum, indicating that the timber maximum production potential has been attained and the tree was
Table 2. Analysis of production potential of mangrove wood at Plot 2

\begin{tabular}{lllllllll}
\hline No. & n & Age & d & h & f & TV & MAI & CAI \\
\hline & & & & & & & & \\
1 & 110 & 18 & 11 & 2.2 & 0.83 & 1.9 & 0.11 & \\
2 & 80 & 21 & 13 & 2.7 & 0.82 & 2.3 & 0.11 & 0.15 \\
3 & 70 & 24 & 15 & 3.2 & 0.81 & 3.2 & 0.13 & 0.28 \\
4 & 62 & 27 & 17 & 3.7 & 0.80 & 4.2 & 0.15 & 0.32 \\
5 & 57 & 30 & 19 & 4.2 & 0.77 & 5.2 & 0.17 & 0.35 \\
6 & 50 & 33 & 21 & 4.7 & 0.76 & 6.2 & 0.19 & 0.32 \\
7 & 45 & 36 & 23 & 5.2 & 0.72 & 7.0 & 0.19 & 0.27 \\
$\mathbf{8}$ & $\mathbf{4 0}$ & $\mathbf{3 9}$ & $\mathbf{2 5}$ & $\mathbf{5 . 8}$ & $\mathbf{0 . 6 7}$ & $\mathbf{7 . 6}$ & $\mathbf{0 . 2 0}$ & $\mathbf{0 . 2 1}$ \\
9 & 35 & 42 & 27 & 6.2 & 0.65 & 8.1 & 0.19 & 0.15 \\
10 & 30 & 45 & 29 & 6.7 & 0.64 & 8.5 & 0.19 & 0.14 \\
11 & 25 & 48 & 31 & 7.3 & 0.63 & 8.7 & 0.18 & 0.06 \\
Total & $\mathbf{6 0 4}$ & & & & $\mathbf{0 . 7}$ & $\mathbf{6 2 . 9}$ & $\mathbf{1 . 8 2}$ & $\mathbf{2 . 2 6}$ \\
\hline
\end{tabular}

Note: n: number of trees (tree $\left.\mathrm{ha}^{-1}\right)$, d: tree diameter $(\mathrm{cm}), \mathrm{h}$ : branch tree height $(\mathrm{m}), \mathrm{f}$ : tee form factor, TV: total volume $\left(\mathrm{m}^{3}\right.$ $\left.\mathrm{ha}^{-1}\right)$, MAI: mean annual increment $\left(\mathrm{m}^{3} \mathrm{ha}^{-1} \mathrm{yr}^{-1}\right)$, CAI: current annual increment $\left(\mathrm{m}^{3} \mathrm{ha}^{-1} \mathrm{yr}^{-1}\right)$

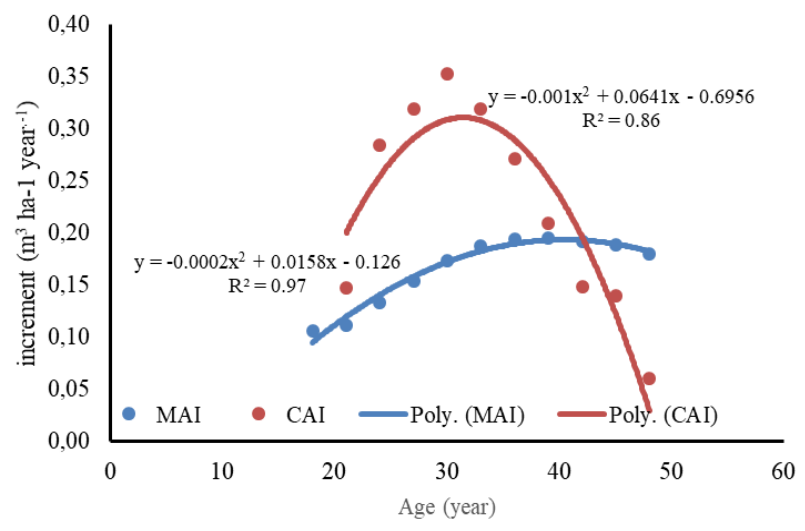

Figure 8. Standing volume increment of mangrove at Plot 2

ready to be cut down. Where MAI and CAI intersect at the values of 0.20 and $0.26 \mathrm{~m}^{3} \mathrm{ha}^{-1} \mathrm{yr}^{-1}$. While the total increment of MAI and CAI mangrove in 1 hectare are respectively at 1.82 and $2.26 \mathrm{~m}^{3} \mathrm{ha}^{-1} \mathrm{yr}^{-1}$. This is supported by a simple linear regression test with the type of polynomial on MAI which has an $\mathrm{R}^{2}$ of $97 \%$. This value means that there is a close relationship between age and MAI increment of $97 \%$ and $3 \%$ influenced by other factors. Whereas the CAI has an $\mathrm{R}^{2}$ of $86 \%$. This value means that there is a close relationship between age and CAI increment of $86 \%$ and $14 \%$ influenced by other factors.

\section{Economic evaluation of mangrove ecosystems in Mentawir Village}

After conducting the identification process, a valuation process or calculation of the economic value of the benefits of the mangrove ecosystem was performed to determine the value of the various benefits. Based on the results of the study, the economic valuation of the mangrove ecosystem in Mentawir Village is as follows: 


\section{Direct use value}

Direct use value is the economic value obtained from the direct use of fishery resources, mangrove wood, and other products (Putranto et al. 2017). In this study, the total direct use value generated from mangrove wood for materials and fisheries was 198.375.000.000 IDR.

The par value of mangrove wood was calculated by multiplying the total volume of wood per ha by the timber selling price (i.e. 500,000 IDR. $\mathrm{m}^{-3}$ ). In the Plot 1 and 2, the total volume of mangrove wood was 102.1 and $62.9 \mathrm{~m}^{3} \mathrm{ha}^{-1}$, respectively, resulted in the average value of mangrove wood of 94,875,000,000 IDR $\mathrm{yr}^{-1}$ with an area of 2,300 ha. The calculation of the economic value of timber products varies across regions. For example, research conducted by Putranto et al. (2017) in coastal islands of Central Sulawesi obtained an economic value of wood of 5,827,227,000 IDR $\mathrm{yr}^{-1}$ with an area of $107 \mathrm{Ha}$, Suzana et al. (2011) obtained an economic value of wood of 273,617,272 IDR $\mathrm{yr}^{-1}$, Zen and Ulfah (2014) in the amount of 26,494,084,500 IDR $\mathrm{yr}^{-}$ 1, Fidyansari and Hastuty (2016) in the amount of 1,325,000 IDR $\mathrm{yr}^{-1}$, Widiastuti et al. (2016) in the amount of $14,219,879,920$ IDR, Wahyuni et al. (2014) in the amount of 407,746,300,000 IDR.yr ${ }^{-1}$, Suzana et al. (2011) in the amount of $10,888,218,123$ IDR $\mathrm{yr}^{-1} \mathrm{ha}^{-1}$, Qodrina

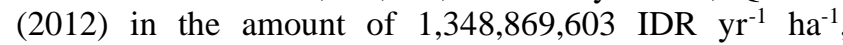
Nanlohy (2013) in the amount of 285,543,161 IDR.yr ${ }^{-1}$, and Soukotta (2013) in the amount of 63.257.034 IDR $\mathrm{yr}^{-1}$.

On the other hand, the par value of fishery products in the form of fish, crab, and shrimp both in plots 1 and 2 with an average selling price of fishery products was 36,000 IDR $\mathrm{kg}^{-1}$, resulted in the par value average of fishery products of 103,500,000.000 IDR $\mathrm{yr}^{-1}$ with an area of 2,300 ha or equivalent to $90,000,000$ IDR $\mathrm{yr}^{-1} \mathrm{ha}^{-1}$. The calculation of previous research conducted by Ariftia et al. (2014) showed the economic value of fishery products of 925,114 IDR $\mathrm{yr}^{-1} \mathrm{ha}^{-1}$, while Osmaleli (2013) was $32,654,428$ IDR $\mathrm{yr}^{-1} \mathrm{ha}^{-1}$, Putranto et al. (2017) amounted to $141,537,809$ IDR, Suzana et al. (2011) was $175,068,000$ IDR.yr ${ }^{-1}$, Zen and Ulfah (2014) were 26,637,368,680 IDR $\mathrm{yr}^{-1}$, Fadhila et al. (2015) was 337,269,000 IDR, Prayogi et al. (2016) was 26,182 IDR billion. $\mathrm{yr}^{-1}$, Fidyansari and Hastuty (2016) were 63,000,000 IDR $\mathrm{yr}^{-1}$, Setyowati et al. (2016) was 1,390,787,140 IDR $\mathrm{yr}^{-1}$, Widiastuti et al. (2016) was $150,148,781,610 \mathrm{IDR} \mathrm{ha}^{-1}$, Putera and Sallata (2015) were 13,104,000,000 IDR, and Nanlohy (2013) was $16,362,912 \mathrm{IDR} \mathrm{yr}^{-1}$. The difference can be caused by the amount of catch per year, market prices, and the condition of mangrove ecosystems in each region. This is also supported by Setiyowati et al. (2016) that the direct use value of mangroves is influenced by the price, volume and condition of each mangrove ecosystem

\section{Indirect use value}

Indirect use value at the study site was manifested as its value as a breakwater, abrasion restraints, and carbon storage. The calculation of the value of this benefit was performed using a replacement cost approach by calculating the costs required to build a breakwater and abrasion restraints, and the price of carbon market. The total indirect use value were $268,158,722,584$ IDR
The replacement cost to build a breakwater and abrasion restraints referred to the Minister of Public Works Regulation Document No. 11/PRT/M/2013 concerning Guidelines for Analysis of the Price of Public Works in 2013 issued by the Public Works Research and Development Agency in 2013. Based on the analysis of the price of the work unit for a breakwater building with a length of $150 \mathrm{~m}$, width $20 \mathrm{~m}$, and height $5 \mathrm{~m}$, the cost was

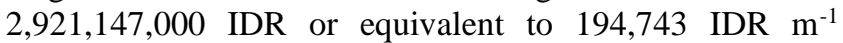
(2016), which becomes $235,240 \mathrm{IDR} \mathrm{m}^{-1}$ if compounded to 2019. Assuming that for the construction of breakwater along the coastline in Mentawir Village, which is $8,083 \mathrm{~m}$, covering an area of 2,300 ha with a durability of 20 years, a value of $38,028,881,407$ IDR is obtained for 20 years or $1,901,444,070$ IDR.yr ${ }^{-1}$. The value of indirect benefits of the mangroves as an abrasion barrier is $218,549,528,110$ IDR for 10 years. Our results differ with Osmaleli's (2013) research, who estimated the cost of breakwater construction was 1,010,000 IDR per year or 17,399.00 IDR.yr-1 $\mathrm{ha}^{-1}$. Kurniawati and Pangaribowo (2017) estimated costs of 3,734,734 IDR.yr ${ }^{-1} \mathrm{ha}^{-1}(2016)$ or 14,122,055 IDR $\mathrm{yr}^{-1}$, Prayogi et al. (2016) 12,698,901,112 IDR ha h $^{-1}$ and Fidyansari and Hastuty (2016) 2,784,931,510 IDR $\mathrm{yr}^{-1}$. Widiastuti et al. (2016) estimated costs of 39,857,181,000 IDR ha ${ }^{-1}$, Putera and Sallata (2015) 20,319,540,000 IDR, Wahyuni et al. (2014) 37,133,936,369 IDR.yr ${ }^{-1}$, Nanlohy (2013) 261,968,211 IDR yr ${ }^{-1}$, Soukotta (2013) 49,829,326 IDR $\mathrm{yr}^{-1}$, and Zen and Ulfah (2014) 35,040,000,000 IDR $\mathrm{yr}^{-1}$.

The indirect use value of mangroves as carbon sinks is $11,580,313,067$ IDR, assuming a carbon price of 8.5 USD ton $^{-1}$ covering 2,300 ha of mangroves. This is different from the study by Prayogi et al. (2016) who estimated $531,015,534$ IDR for the mangrove area of 321 ha with an indirect use value of $268,084,583,762$ IDR. The key factor in the calculation of this value is the extent of mangroves, the length of the coastline, and the value of foreign exchange. This is also supported by Setiyowati et al. (2016) that the indirect use value of mangroves is influenced by length of the coastline and foreign exchange.

\section{Option value}

The option value is was defined as benefits derived from biodiversity. According to Ruitenbeek (1992),

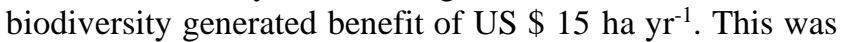
then applied to obtain a rough estimate of the value of the selected benefits at the study site. The technique for calculating biodiversity values at the study site was slightly different from other locations in general. Ruitenbeek (1992) only multiplied the value of the biodiversity benefit by the mangrove area in each area, whereas at the research location the calculation was updated by incorporating compound interest for actual values at the respective year (i.e. 2019).

Assuming the biodiversity value at the study location was 15 USD ha $\mathrm{yr}^{-1}$ in 1992, an exchange rate of 1 USD was 14,500 IDR, the current value was updated for 27 years (1992-2019) with a deposit interest rate of $17 \%$ year1 , and an area of 2,300 ha mangrove. All these resulted a total biodiversity value in the mangrove ecosystems of 
Mentawir Village of 34,690,085,038 IDR.yr ${ }^{-1}$. This contrasts to research conducted by Putranto et al. (2017) who found a biodiversity value of $31,346,500$ IDR.yr-1, Suzana et al. (2011) 41,297,640 IDR.yr ${ }^{-1}$, Zen and Ulfah (2014) 90,877,800 IDR.yr-1 ${ }^{-1}$ Fadhila et al. (2015) $8,885,338$ IDR $\mathrm{yr}^{-1}$, Prayogi et al. (2016) 10,615,567,584 IDR $\mathrm{yr}^{-1}$, Fidyansari and Hastuty (2016) 405,600 IDR.yr ${ }^{-1}$, Setyowati et al. (2016) 911,640 IDR yr ${ }^{-1}$, Widiastuti et al. (2016) 1,977,396,451 IDR $\mathrm{yr}^{-1}$, Kurniawati and Pangaribowo (2017) 3,734,734 IDR ha-1 $\mathrm{yr}^{-1}$, Wahyuni et al. (2014) 35,571,600,000 IDR, Nanlohy (2013) 1,703,065 IDR.yr ${ }^{-1}$, Soukotta (2013) 1,319,787 IDR $\mathrm{yr}^{-1}$, and Zen and Ulfa (2014) in the amount of $90,877,800$ IDR $\mathrm{yr}^{-1}$. What distinguishes this value calculation is the extent of mangroves and the foreign exchange as well as interest rate.

\section{Existence value}

The existence value of mangrove ecosystems was defined as willingness to pay (WTP) and willingness to accept (WTA) that represents someone concern to maintain the quality of the environment of the mangrove ecosystem. The approaching model of WTP of wood is assumed as the ability of the community to pay for natural and environmental services in mangrove conservation activities whose value is obtained from mangrove wood products. While the WTA model of fish catch is assumed to be the willingness of the community to receive "compensation" (compensation funds) derived from fish catches. This refers to research that has been done by Kristiningrum et al. (2019). The value of the margin (profit) from both WTPs and WTAs is made as to the balance value as set out in Tables 3 and 4.

Based on Table 3 above it can be explained that the WTPs from mangrove at Plot 1 is assumed to be the amount of community costs that must be spent to pay for natural/environmental services starting at the age of 24 to 54 years. This is to be consistent with the mangrove stand potential data (Table 1). The total WTPs to be paid from the year 24 to 54 ranged from 1.84 to 6.61 IDR million ha ${ }^{-1}$ with average WTP (AWTP) of 0.08 to 0.13 IDR million ha ${ }^{1}$ year $^{-1}$. The optimal point of AWTP and MWTP is reached at the age of 45 years with the amount of costs that must be incurred at 0.13 IDR million ha $^{-1}$ year $^{-1}$.

WTA is assumed as the amount of compensation funds received by the community due to natural/environmental services in the form of catches starting at the age of 24 to 54 years as per rationale above. The total WTA to be received from 24 to 54 years ranged from 4.03 to 7.36 IDR million ha ${ }^{-1}$ with average WTA (AWTA) from 0.17 to 0.13 IDR million $\mathrm{ha}^{-1} \mathrm{yr}^{-1}$. The optimal point of AWTA and MWTA is reached at the age of 48 years with the amount of funds received amounting to 0.13 IDR million $\mathrm{ha}^{-1} \mathrm{yr}^{-1}$. The graphical explanation of the curves of WTP, WTA, and the margin balance can be seen in Figure 9.

Using the margin between WTP and WTA of 0.13 IDR million $\mathrm{ha}^{-1} \mathrm{yr}^{-1}$ and assuming the total area of mangrove forests in Mentawir Area is 2,300 ha, then the total margin of WTP and WTA is 299 million IDR $\mathrm{yr}^{-1}$. Using a simple linear regression to test the relationship between age and the marginal values resulted in determination coefficient $\left(\mathrm{R}^{2}\right)$ of $93 \%$ for WTP and $88 \%$ for WTA, meaning there is a close relationship between age and the marginal values.

Whereas the WTP and WTA balance margins at Plot 2 can be seen in Table 4.

The total WTPs to be paid starting from the year 18 to 48 ranged from 0.63 to 3.52 IDR million ha $^{-1}$ with average WTP (AWTP) of 0.04 to 0.08 IDR million $\mathrm{ha}^{-1} \mathrm{yr}^{-1}$. The optimal point of AWTP and MWTP is reached at the age of 39 years with the amount of costs that must be incurred in the amount of 0.08 IDR million. $\mathrm{ha}^{-1} \mathrm{yr}^{-1}$. Whereas the total WTA to be received starting from the year 18 to 48 ranged from 1.84 to 3.93 IDR million ha $^{-1}$ with average WTA (AWTA) of 0.08 to 0.10 IDR million $\mathrm{ha}^{-1} \mathrm{yr}^{-1}$. The optimal point of AWTA and MWTA in plot two is reached at the age of 39 years with the amount of funds received amounting to 0.08 IDR million ha $^{-1}$ year ${ }^{-1}$ or equal to 184 million IDR million $\mathrm{yr}^{-1}$ if applied to the area of 2300 ha. The graphical explanation of the curves of WTP, WTA, and the margin balance can be seen in Figure 10.

Table 3. WTP of mangrove wood and WTA of fish catch at Plot 1

\begin{tabular}{|c|c|c|c|c|c|c|c|}
\hline Year & $\begin{array}{c}\text { TWTP } \\
\text { (IDR } \\
\text { million } \\
\text { ha }^{-1)}\end{array}$ & $\begin{array}{c}\text { AWTP } \\
\text { (IDR } \\
\text { million } \\
\left.\text { ha }^{-1} \mathbf{y r}^{-1}\right)\end{array}$ & $\begin{array}{c}\text { MWTP } \\
\text { (IDR } \\
\text { million } \\
\left.\text { ha }^{-1} \mathbf{y r}^{-1}\right)\end{array}$ & Year & $\begin{array}{c}\text { TWTA } \\
\text { (IDR } \\
\text { million } \\
\text { ha }^{-1)}\end{array}$ & $\begin{array}{c}\text { AWTA } \\
(\text { IDR } \\
\text { million } \\
\text { ha }^{-1} \mathbf{y r}^{-1} \text { ) }\end{array}$ & $\begin{array}{l}\text { MWTA } \\
\text { (IDR } \\
\text { million } \\
\text { ha }^{-1} \mathbf{y r}^{-1} \text { ) }\end{array}$ \\
\hline 24 & 1.84 & 0.08 & & 24 & 4.03 & 0.17 & \\
\hline 27 & 2.64 & 0.10 & 0.27 & 27 & 4.10 & 0.15 & 0.03 \\
\hline 30 & 3.37 & 0.11 & 0.24 & 30 & 4.25 & 0.14 & 0.05 \\
\hline 36 & 4.60 & 0.13 & 0.19 & 36 & 4.73 & 0.13 & 0.10 \\
\hline 39 & 5,07 & 0.13 & 0.16 & 39 & 5.07 & 0.13 & 0.11 \\
\hline 42 & 5.46 & 0.13 & 0.13 & 42 & 5.46 & 0.13 & 0.13 \\
\hline 45 & 5.85 & 0.13 & 0.13 & 45 & 5.85 & 0.13 & 0.13 \\
\hline 48 & 6.24 & 0.13 & 0.08 & 48 & 6.24 & 0.13 & 0.16 \\
\hline 51 & 6.47 & 0.13 & 0.04 & 51 & 6.71 & 0.13 & 0.22 \\
\hline 54 & 6.61 & 0,12 & 0.03 & 54 & 7.36 & 0.14 & 0.31 \\
\hline
\end{tabular}

Note: TWTP: total willingness to pay, AWTP: average willingness to pay, MWTP: marginal willingness to pay, TWTA: total willingness to accept, AWTA: average willingness to accept, MWTA: marginal willingness to accept

Table 4. WTP of mangrove wood and WTA of fish catch at Plot 2

\begin{tabular}{|c|c|c|c|c|c|c|c|}
\hline Year & $\begin{array}{c}\text { TWTP } \\
\text { (IDR } \\
\text { million } \\
\text { ha }^{-1)}\end{array}$ & $\begin{array}{c}\text { AWTP } \\
\text { (IDR } \\
\text { million } \\
\mathrm{ha}^{-1} \mathrm{yr}^{-1} \text { ) }\end{array}$ & $\begin{array}{c}\text { MWTP } \\
\text { (IDR } \\
\text { million } \\
\text { ha }^{-1} \mathbf{y r}^{-1} \text { ) }\end{array}$ & Year & $\begin{array}{c}\text { TWTA } \\
\text { (IDR } \\
\text { million } \\
\text { ha }^{-1)} \\
\end{array}$ & $\begin{array}{c}\text { AWTA } \\
\text { (IDR } \\
\text { million } \\
\text { ha }^{-1} \mathbf{y r}^{-1} \text { ) }\end{array}$ & $\begin{array}{c}\text { MWTA } \\
\text { (IDR } \\
\text { million } \\
\text { ha }^{-1} \mathbf{y r}^{-1} \text { ) } \\
\end{array}$ \\
\hline 18 & 0.63 & 0.04 & & 18 & 1.84 & 0.10 & \\
\hline 21 & 0.11 & 0 & 0.16 & 21 & 1.90 & 0.0 & 0.02 \\
\hline 24 & 1.54 & 0 & & 24 & 2.01 & 0.0 & 0.04 \\
\hline 27 & 1.95 & $0 .($ & & 27 & 2.16 & $0 .($ & 0.05 \\
\hline 30 & 2.28 & 0.08 & & 30 & 2.35 & 0.0 & 0.06 \\
\hline 33 & 2.56 & 0.08 & & 33 & 2.56 & 0.0 & 0.07 \\
\hline 36 & 2.79 & & & 36 & 2.79 & 0.0 & 0.08 \\
\hline 39 & 3.03 & & & 39 & 3.03 & 0. & 0.08 \\
\hline 42 & 3.26 & & & 42 & 3.26 & & 0.10 \\
\hline 45 & 3.42 & & & 45 & 3.56 & 0. & 0.12 \\
\hline 48 & 3.52 & 0.07 & 0.02 & 48 & 3.93 & 0.08 & 0.16 \\
\hline
\end{tabular}

Note: TWTP: total willingness to pay, AWTP: average willingness to pay, MWTP: marginal willingness to pay, TWTA: total willingness to accept, AWTA: average willingness to accept, MWTA: marginal willingness to accept 


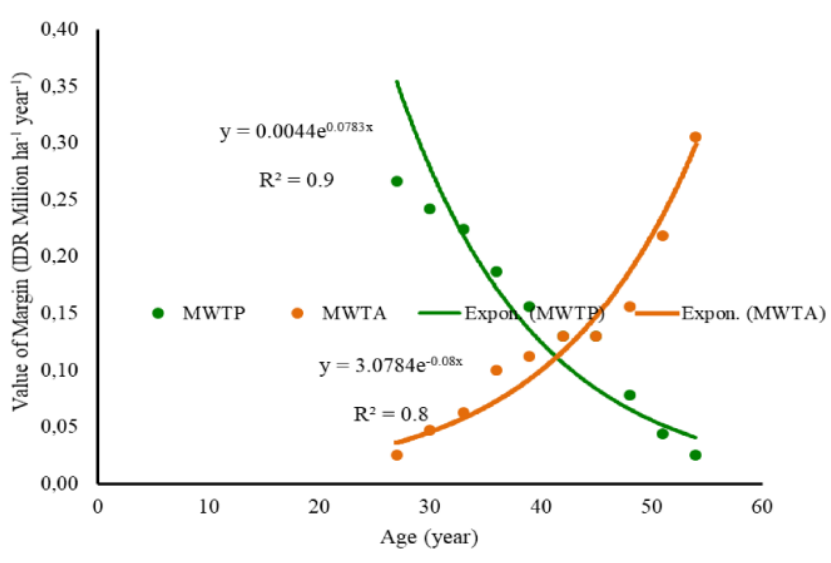

Figure 9. Balance margin between WTP of mangrove wood and WTA of fish catch at Plot 1

Table 5. Total economic value (TEV) of mangrove ecosystems in Mentawir Village

\begin{tabular}{lll}
\hline Type of value & Value (IDR) & Percentage \\
\hline Direct use value & $198,375,000,000$ & 39.56 \\
Indirect use value & $268,158,722,584$ & 53.48 \\
Option value & $34,690,085,038$ & 6.92 \\
Existence value & $241,500,000$ & 0.05 \\
Total economiv value (TEV) & $501,465,307,621$ & 100 \\
\hline
\end{tabular}

Linear regression to test the relationship between age and the marginal values resulted in determination coefficient $\left(\mathrm{R}^{2}\right)$ of $92 \%$ for WTP and $90 \%$ for WTA, meaning there is a close relationship between age and the marginal values.

So if taken the average of both Plot 1 and Plot 2, the value of the existence of $241,500,000$ IDR ha ${ }^{-1} \mathrm{yr}^{-1}$. A similar study was conducted by Setyowati et al. (2016) a WTP value of 5,652,958 IDR $\mathrm{ha}^{-1} \mathrm{yr}^{-1}$, Widiastuti et al. (2016) of 3,074,276,220 IDR, Kurniawati and Pangaribowo (2017) of 36,647 IDR ha-1 $\mathrm{yr}^{-1}$. Indriyanti et al. (2015) 26,564 IDR ha ${ }^{-1} \mathrm{yr}^{-1}$, Wahyuni et al. (2014) 13,305,625,000 IDR $\mathrm{ha}^{-1} \mathrm{yr}^{-1}$, Nanlohy (2013) in the amount of $1,703,065$ IDR $\mathrm{ha}^{-1} \mathrm{yr}^{-1}$, Soukotta (2013) in the amount of 2,730,000 IDR $\mathrm{ha}^{-1} \mathrm{yr}^{-1}$, whereas according to Kristiningrum et al. (2019) it ranges between 307,000,000 IDR ha-1 $\mathrm{yr}^{-1}$.

\section{Total economic value}

Total economic value is the sum of the direct, indirect, option and existence value. The TEV of the mangrove ecosystem in Mentawir Village amounted to $501,391,168,800$ IDR (Table 5) with the largest portion was contributed by indirect use value $(53.47 \%)$, followed by direct use value $(39.56 \%)$. The option value and existence value contributed only $6.92 \%$ and $0.05 \%$, respectively.

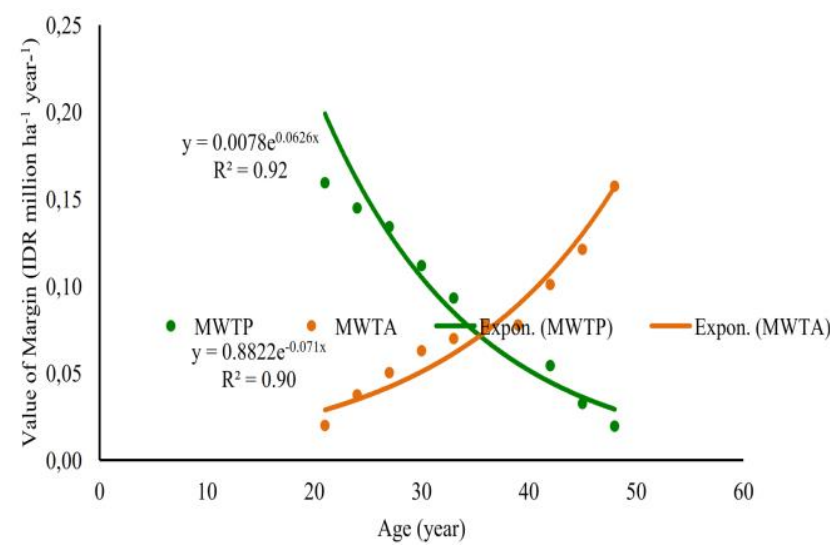

Figure 10. Margin balance between WTP of mangrove wood and WTA of fish catch at Plot 2

The TEV above indicates that the mangrove ecosystem in the study location has a greater ecological value than its socioeconomic value. Similar results were also found in the research of Ariftia et al. (2014) and Indrayanti et al. (2015), while Hiariey (2009) and Osmaleli (2013) obtained the opposite result. There are differences in economic values that occur in similar research, partly due to changes in the exchange rate of the IDR against USD, differences in prices and characteristics, or characteristics of each mangrove forest area and the diversity of use by local communities. The value of mangrove resources illustrates its contribution to human welfare, especially in coastal communities, through economic development. This contribution should be balanced with an investment in the conservation of mangrove resources. The economic value of mangrove ecosystems can increase public investment in the form of knowledge of the intrinsic value of their natural resources. Knowledge of both values can be the basis of policymakers for managing natural resources so that their ecosystems are more protected and sustainable, and can continue to provide environmental services for the welfare of the community and the region.

\section{ACKNOWLEDGEMENTS}

This research was funded by the Ministry of Research and Technology/National Research and Innovation Agency) Research Scheme Doctoral Dissertation (Announcement number B/87/E3/RA.00/2020 dated January 28, 2020). The authors would like to thank Mr. Lamale who has agreed to be key respondents at the study site, Stain Lotta which has helped in the identification of biodiversity mangroves. We would like to express our gratitude to Rafii and Umbar Sujoko for his help in creating the map of the study site. The authors would like to acknowledge Roni Bawole, Thomas F. Pattiasina and anonymous reviewers for providing constructive comments to improve the manuscript. 


\section{REFERENCES}

Anissa F. 2012. Total economic value of post-rehabilitation mangrove forests in Tlanakan Coastal, Pamekasan Regency, East Java. [Hon. Thesis]. Department of Resource and Environmental Economics Faculty of Economics and Management Bogor Agricultural University, Bogor. [Indonesian]

Ariftia RI, Qurniati R, Herwanti S. 2014. The total economic value of mangrove forests in the Margasari village, Laring Maringgai district, East Lampung Regency. J Sylva Lestari 2 (3): 19-28. [Indonesian]

Atmoko T, Ma'ruf A, Syahbani, Rengku MT.2007. Habitat and distribution conditions bekantan (Nasalis larvatus Wurmb) in the Mahakam Delta, East Kalimantan. In: Sidiyasa K, Omon M, Setiabudi D. (eds.). Proceedings of the Seminar on the Utilization of NTFPs and Biodiversity Conservation towards Sustainable Forests. Balikpapan, January 31, 2007. R and D Center Forests and Nature Conservation, Bogor. [Indonesian]

Atmoko T, Ma'ruf A, Rinaldi SE, Sitepu BS. 2011. Spread of proboscis monkey (Nasalis larvatus Wurmb.) In Balikpapan Bay, East Kalimantan. Proceedings of the seminar on Samboja BPTKSDA research results, Samarinda. [Indonesian]

Barbier EB, Hacker SD, Kennedy C, Koch EW, Stier EC, Silliman BR. 2011. The value of estuarine and coastal ecosystem services. Eco Monogr 81 (2): 169-193.

Bonita MK, Wahyu YN. 2014. Analisis Kerusakan Hutan Mangrove Di Wilayah Pesisir Sekotong Kabupaten Lombok Barat. Jurnal Media Bina Ilmiah 8 (1): 64-71. [Indonesian]

Correa DA, Oliveira DM. 2008. Composition of the aquatic invertebrate fauna associated to the mangrove vegetation of a coastal river, analysed through a manipulative experiment. Pan-Am. J Aquat Sci 3: 23-31.

Darmawan. 2015. Economic valuation of ecosystem services in the Mount Menumbing Tourist Area in West Bangka Regency. Bandung. Padjadjaran University. [Indonesian]

Dinga E. (2014). On a possible predictor of the cyclical position of the economy. J Procedia Econ Finance: 254-261.

FAO. 2008. Forests and water: A Thematic study prepared in the Framework of the 2005 global forest resources assessment FAO Forestry. Paper 153. FAO, Rome.

Fadhila H, Saputra, Wijayanto. 2015. Nilai manfaat ekonomi ekosistem mangrove di desa kartika jaya kecamatan patebon kabupaten kenda jawa tengah. J Maquares Manag Aquat Resour 4 (3): 180-187. [Indonesian]

Fauzi A, Anna S. 2005. Guidelines for economic valuation of marine protected areas (MPAs). Ministry of Maritime Affairs and Fisheries, Directorate of Conservation, Directorate General of Coastal and Small Islands.

Fauzi A. 2014. Economic valuation and assessment of damage to natura resources and the environment. Bogor: IPB Press. [Indonesian]

Fidyansari D, Hastuty S. 2016. Valuasi ekonomi ekosistem mangrove di desa Barowa Kecamatan Bua Kabupaten Luwu. Perbal: Jurnal Pertanian Berkelanjutan, 4 (3): 1-14. [Indonesian]

Halkos GE, Galani GK. 2013. Economic foundations to assess non-market values in marine and coastal ecosystems water quality. J Environ Manag Tourism. 4 (1): 5-20.

Hanley N, Spash CL. (1993). Cost Benefit Analysis and The Environment. Edward Elgar Publishing Limited, Cheltenham, England.

Hutapea MCL. 2016. The attraction of Balikpapan Bay ecotourism. Brief Info.

Kamaludin M, Aziz AA, Ibrahim, NSC, Radam AA. 2018. A survey on willingness to pay for domestic water service attributes in Terengganu, Malaysia. J Sustain Sci Manag: 133-144.

Kristiningrum R, Lahjie A, Masjaya, Yusuf S, Ruslim Y. 2019. Species diversity, stand productivity, aboveground biomass and economic value of mangrove ecosystem in Mentawir Village, East Kalimantan, Indonesia. Biodiversitas 20 (10): 2848-2857. [Indonesian]

Kurniawati N D, Pangaribowo EH. 2017. Valuasi Ekonomi Ekosistem Mangrove di Desa Karangsong, Indramayu. Jurnal Bumi Indonesia 6(2): 1-12. [Indonesian]

Kwatrina RT, Takandjandji M. 2011. The Value of mangrove ecosystems in the Blana Beach tourism area. Forest Info 7 (2): 271-282. Research and Development Center for Conservation and Rehabilitation. Forestry Research and Development Agency. Bogor. [Indonesian]
Lahjie AM, Nauval B, Lahjie AA, Ruslim Y, Kristiningrum R. 2019. Economic valuation from direct use of mangrove forest restoration in Balikpapan Bay, East Kalimantan, Indonesia. F1000Research 8: 1-13. DOI: 10.12688/f1000research.17012.1.

Lhota S. 2010. Is there any future for proboscis monkeys? The case of failing conservation of Balikpapan Bay. Abstract International Primatology Society XXIII Congress Kyoto, Japan

Lundquist C. Carter K. Hailes S. and Bulmer R. 2017. Guidelines for Managing Mangroves (Mānawa) Expansion in New Zealand. NIWA Information, Series No. 85. National Institute of Water \& Atmospheric Research Ltd., NZ.

Malik, Abdul, Rasmus, Fensholt, Mertz, Ole. 2015. Economic valuation of mangroves for comparison with commercial aquaculture in South Sulawesi, Indonesia. Forests 6 (9): 3028-3044.

Marhayana S, Niartiningsih A, Idrus R. 2012. Economic benefits of mangrove ecosystems in Padaido Aquatic Park in Biak Numfor Regency, Papua. Faculty of Maritime Sciences and Fisheries, Hasanuddin University, Makassar. [Indonesian].

Masrizal. 2011. Mixed-Method Research. Jurnal Kesehatan Masyarakat Andalas 6 (1): 53-56. [Indonesian]

Ministry of Public Works. 2014. Attachment of minister of public works regulation No. 11/2013, Guidelines for Building Construction Materials and Civil Engineering. Ministry of Public Works, Jakarta. [Indonesian]

Mitchell and Carson. 1989. Using surveys to value public goods the contingent valuation method. Resources for the Future, Washington DC

Motoku AW, Umar S, Toknok B. 2014. Nilai Manfaat Hutan Mangrove Di Desa Sausu Peore Kecamatan Sausu Kabupaten Parigi Moutong. Jurnal Warta Rimba 2 (2): 92-101. [Indonesian]

Muliadi M, Lahjie AM, Simarangkir BDAS, Ruslim Y. 2017. Bioeconomic and environmental valuation of dipterocarp estate forest based on local wisdom in Kutai Kartanegara, Indonesia. Biodiversitas 18 (1): 401-408

Nanlohy H. 2013. Valuasi ekonomi ekosistem hutan mangrove di desa waiheru kota ambon. Pena Jurnal Ilmu Pengetahuan dan Teknologi 25 (1): 15-21. [Indonesian]

Suzana BOL, Timban J, Kaunang R, Ahmad F. 2011. Valuasi Ekonomi Sumberdaya Hutan Mangrove Di Desa Palaes Kecamatan Likupang Barat Kabupaten Minahasa Utara. Agri-Sosioekonomi 7 (2): 29-38. [Indonesian]

Oktawati NO, Sulistianto E. 2015. Study of mangrove ecosystem management in Kariangau Village, West Balikpapan District Through an Economic Approach. Borneo Harpodon J: 113-121.

Osmaleli. 2013. Economic analysis and policy for sustainable management of mangrove ecosystems in the Village of Customs Udik, Indramayu Regency. [Thesis]. IPB, Bogor. [Indonesian]

Pearce DW, Turner RK. 1990. Economics of natural resources and the environment. The Johns Hopkins University Press, Baltimore.

Putera FHA, Sallata AE. 2015. Valuasi ekonomi sumberdaya di Teluk Palu, Kota Palu, Provinsi Sulawesi Tengah. Jurnal Kebijakan Sosial Ekonomi Kelautan Perikanan 5 (2): 83-87.

Putranto S, Zamani NP, Sanusi HS, Riani E, Fahrudin A. 2017. Valuasi ekonomi sumberdayahutan mangrove di pesisir Kabupaten Banggai dan Banggai kepulauan sulawesi tengah. Jurnal Ilmu dan Teknologi Kelautan Tropis 9 (2): 645-656

Prayogi H, Wijayanto D, Raysina N. 2016. Kajian valuasi ekonomi hutan mangrove di Desa Pantai Mekar, Kecamatan Muara Gembong, Kabupaten Bekasi. [Thesis]. Universitas Diponegoro, Semarang. [Indonesian]

Price R.2007. An Introductory guide to valuing ecosystem services. Department of Environment, Food and Rural Affairs, London.

Qodrina H R. 2012. Economic valuation of mangrove ecosystems in Teluk Pambang Village, Bantan District, Bengkalis Regency, Riau Province. Environ Sci 6 (2): 93-98.

Rao K. 2000. Sustainable development-economics and policy. Blackwell Publisher, Oxford.

Ridzwan A, Bernard MH, Hanya G. 2009. The population size and distribution of Proboscis Monkeys (Nasalis larvatus) based on a brief study in Garama, Klias Peninsula, Sabah, Malaysia. J Trop Biol Conserv 5: 67-70.

Rizal A, Dewanti LP. 2017. Using economic value to evaluate management options for fish biodiversity in the Sikakap Strait, Indonesia. Biodiversitas 18 (2): 575-581. [Indonesian] 
Ruitenbeek, HJ. 1992. Mangrove management an economic analysis of management option with a focus on Bintuni Bay, Irian Jaya Dalhousie University Printing Center, Canada.

Saenger P. 2011. Mangroves: sustainable management in Bangladesh. In Günter S, Weber M, Stimm B, Mosandl R, eds. 2011. Silviculture in the Tropics. Springer Verlag, Berlin.

Salter RE, MacKenzie NA. 1985. Conservation Status of the Proboscis Monkey in Sarawak. Bio Conserv 33: 119-132.

Samsul R. 2013. The Total economic value of mangrove ecosystems on Rumberpon Island. [Thesis] Faculty of Forestry, State University of Papua, Manokwari. [Indonesian]

Wuthiya S. (2016). Estimating willingness to pay for safe beef. J Environ Manag Tourism 7 (13): 94-104.

Sari M. 2012. Types of mangrove forest fauna in the PT Bina Ovivipari Semesta and surrounding areas. PT Bina Ovivipari Semesta, Sei. Raya. [Indonesian]

Setiyowati D, Supriharyono S, Triarso I. 2017. Valuasi ekonomi sumberdaya mangrove di Kelurahan Mangunharjo, Kecamatan Tugu, Kota. Saintek Perikanan: Indonesian J Fish Sci Tech 12 (1): 67-74 [Indonesian]

Sina I, Maryunani, Batoro J, Harahab N. 2017. Analysis of total economic value of ecosystem mangrove forest in the coastal zone pulokerto village district of Kraton Pasuruan Regency. Intl J Ecosyst 7 (1): 110.

Soukotta LM. 2013. Valuasi ekonomi ekosistem hutan mangrove di Negeri Tawiri Kota Ambon. Jurnal Ilmu Pengetahuan dan Teknologi 25 (1): 1-7. [Indonesian]

Sugiyono. 2015. Combined research methods (mix methods). Alfabeta Bandung. [Indonesian]

Suprapto S, Kirana M, Susilowati I, Fauzi A. (2016). Economic Valuation of Mangrove Restoration in Indonesia. Jurnal Ekonomi Pembangunan: Kajian Masalah Ekonomi dan Pembangunan 16 (2): 121-130. [Indonesian]

Suzana, BOL, Weigh, Kaunag, Ahmad. 2011. Economic valuation of mangrove forest resources in Palaes Village, West Likupang District, North Minahasa Regency. ASE 7 (2): 29-38.

Tuwo. 2011. Pengelolaan ekowisata pesisir dan laut: pendekatan ekologi, sosial-ekonomi, kelembagaan, dan sarana wilayah. Brilian Internasional, Sidoarjo. [Indonesian]
Van Gardingen MM. 2003. Financial and ecological analysis of management options For logged-over dipterocarp forest in Indonesia Borneo. For Ecol Manag 73: 259-270.

Vegh T, Jungwiwattanaporn M, Pendleton L, Murray B. 2014. Mangrove ecosystem services valuation: state of the literature. Working Paper Duke University, Durham, NC.

Vo QT, Kuenzer C, Vo QM, Moder F, Oppelt N. 2012. Review of valuation methods for mangrove ecosystem services. Ecol Indic 23: 431-446.

Wang M, Huang Z, Shi F, Wang W. 2009. Are vegetated areas of mangroves attractive to juvenile and small fish? The case of Dongzhaigang Bay, Hainan Island, China. Estuar Coast Shelf Sci 85: 208-216.

Wahyuni Y, Putri EIK, Simanjuntak SM. 2014. Valuasi total ekonomi hutan mangrove di Kawasan Delta Mahakam Kabupaten Kutai Kartanegara Kalimantan Timur. Jurnal Penelitian Kehutanan Wallacea 3 (1): 1-12. [Indonesian]

Walters BB, Rönnbäck P, Kovacs JM, Crona B, Hussain SA, Badola R, Primavera JH, Barbier E, Dahdouh-Guebas F. 2008. Ethnobiology, socio-economics and management of mangrove forests: A review. Aquat Bot 89: 220-236.

Endayani, S. Komposisi Vegetasi waMangrove di Teluk Balikpapan Provinsi Kalimantan Timur. Agrifor 16 (1): 115-124.

Widiastuti MMD, Ruata NN, Arifin T. 2016. Valuasi ekonomi ekosistem mangrove di wilayah pesisir Kabupaten Merauke. Jurnal Sosial Ekonomi Kelautan dan Perikanan 11 (2): 147-159. [Indonesian]

Wijaya S. 2018. Sustainable marine and fisheries development in supporting Indonesia as the world maritime axis. Maritime and Fisheries Research and Human Resources Agency, Jakarta.

Winarni B, Lahjie AM, Simarangkir BDAS, Yusuf S, Ruslim Y. 2017. Tengkawang cultivation model in community forest using agroforestry system in West Kalimantan, Indonesia. Biodiversitas 18 (2): 765-772.

Zakarian M, Rajpar Mn. 2015. Assessing the fauna diversity of Marudu Bay mangrove forest, Sabah, Malaysia, for future conservation. Divers 7 (2): 137-148.

Zen LW, Ulfa F. 2014. Valuasi ekonomi hutan mangrove di pulau dompak kota Tanjungpinang Propinsi Kepulauan Riau. Dinamika Maritim 4 (1): 45-52 . [Indonesian] 